Tanzania Journal of Science 47(3): 969-980, 2021
ISSN 0856-1761, e-ISSN 2507-7961

\title{
Local Communities' Awareness on Payments for Ecosystem Services for Improved Livelihood and Conservation of Nyando Wetland, Kenya
}

\author{
Joseph K. Maithya ${ }^{1}$, Felix L.M. Ming'ate ${ }^{2^{*}}$ and Sammy C. Letema ${ }^{3}$ \\ ${ }^{1}$ Department of Landscape and Environmental Science, Jomo Kenyatta University of Agriculture \\ and Technology, P. O. Box 62,000-00200, Nairobi, Kenya. E-mail: jmaithya@jkuat.ac.ke \\ ${ }^{2}$ Department of Environmental Studies and Community Development, Kenyatta University, P.O. \\ Box 43844-00100, Nairobi, Kenya. E-mail:mingate.felix@ku.ac.ke \\ ${ }^{3}$ Department of Environmental Planning and Management, Kenyatta University, P. O. Box 43844- \\ 00100 Nairobi, Kenya. E-mail: letema.sammy@ku.ac.ke \\ *Corresponding author
}

Received 17 May 2021, Revised 11 Jul 2021, Accepted 20 Jul 2021, Published Aug 2021

DOI: https://dx.doi.org/10.4314/tjs.v47i3.8

\begin{abstract}
Nyando wetland provides several ecosystem goods and services, i.e., provisioning, cultural, supporting and regulating which are essential for human well-being for making life possible and worth living. Payment for Ecosystem Services presents one key question in current literature on whether local communities are aware of ecosystem services provided by wetlands. This paper contributes to the understanding of the local community's level of awareness of the ecosystem services provided by Nyando wetland in Kenya as a strategy to improve protection of wetlands. The study is significant as it proposes policy options that can assist conservation authorities and local communities in management of wetlands. A stratified random sampling based on two administrative sub-counties, namely Nyando and Nyakach was employed to collect quantitative data from 394 households using a structured questionnaire. The quantitative data was subjected to descriptive statistics and Chi-square test which were performed in SPSS version 20. The results confirmed that the local community is more conversant with the provisioning ecosystem services (37.7\%) compared to the other classes of ecosystem services. Despite the locals being involved in community based natural resource conservation initiatives, majority of the respondents (69\%) were not familiar with the concept of Payment for Ecosystem Services. Therefore, there is need to create awareness and capacity building to local communities on the importance of both the wetland ecosystem services and Payment for Ecosystem Services in conservation of wetlands for enhanced community livelihoods.
\end{abstract}

Keywords: Payment for ecosystem services, wetland, conservation, community, livelihood, awareness.

\section{Introduction}

Globally, environmental governance is heading towards schemes that can value and manage natural resources in order to support specific social and economic goals (Li 2007, Dressler 2011, To et al. 2012). This is normally done by creating a market for ecosystem services through Payment for Ecosystem Services (PES) that enables the local people to generate income from harvesting fewer higher value resources than more extensive or destructive modes of production (Pagiola et al. 2005, To et al. 2012). Wunder (2005) and Báliková et al. (2020) explained that PES is a 
voluntary transaction, involving the conditional purchase of a well-defined environmental service by a buyer from a seller. The willingness by the local communities to accept PES is meant to improve the quality of the provisioning goods and services such as adequate quality water, improved food security and improved supporting services such as soil nutrient cycling and regulating services like floods and soil erosion control, climate regulation, water purification, and pollination (Nyongesa et al. 2016). The practice of PES has been considered as one of the most viable approaches of incorporating communities in natural resource management in Eastern and Central Africa (Berttram 2011). This has a huge potential for protecting wetlands, improving livelihoods and well-being for communities inhabiting wetland areas (Wanjohi et al. 2011).

Payment for wetland ecosystem services can contain restricting land use technologies such as reduction in agricultural expansion, rehabilitation, reduced deforestation and reforesting areas which have been degraded. It also entails improvement of cropping systems or practices such as agroforestry, silvopasturing, reduced logging, improved conservational agricultural practices-no-tillage, no-burning, and organic agriculture (Wunder and Boerner 2010). Rewards or PES can either be based on commoditized ecosystem services (CES), compensation for opportunities skipped (COS), which is connected to use-restricting of PES whereby sellers get rewards for actions avoided and co-investment in ecosystem services (CIS), which is connected to usemodification PES schemes (Noorwijk and Leimona 2010). Incentives for PES can be given in form of direct money payments or in kind. Land managers or resource stewards can either receive monetary payments for a bundled or a single ecosystem service or can also receive in kind payments such as market access, access to information and training, land use rights, and access to protected areas (Swallow et al. 2007).
Valuing of ecosystem services can include economic and non-economic values such as ecological, aesthetic, bequest, health, spiritual values amongst others (Gómez-Baggethun et al. 2014). The opponents of economic valuation argue that it can result to 'commodification' of nature opening market trade to previously non-marketed areas which can have some damaging effects such as alienation of people from nature and transforming public services and property into commodities only accessible by the wealthy (Gómez-Baggethun and Ruiz-Perez 2011). However, valuation has been found to be an important tool for use to protect and conserve ecosystem services for the benefit of the society (Atkinson et al. 2012). Depending on the kind of the ecosystem service dealt with, payments can be made at a governmental level to communities and groups or individuals (Sommerville et al. 2009). Every PES participant of the given scheme can either receive an equal amount which is based on average opportunity usually agreed upon initially or may be based on opportunity cost of an individual, land use technologies adopted and land specific biophysical factors.

A number of studies have shown that Africa lags behind in PES schemes than in Asia and Latin America (Ferraro 2009). For instance, Lecocq and Capoor (2005) noted that in 2003 and 2004 markets for global carbon offset, when Africa was accounting for only 3\% of emission reduction projects, Asia and Latin America accounted for more than three quarters of the projects. Of the African projects, South Africa and Uganda contributed to the bulk of the transactions. Even up to 2005, Africa had few PES projects under preparation compared to other parts of the world (Lacocq and Capoor 2005). The reasons for low adoption of the PES in Africa have been identified as lack of enabling legislations and policies (Mwangi and Mutunga 2005, Waage et al. 2006, Scurrah-Ehrhart 2006, Greiber 2009, Kronenberg and Hubacek 2013, Kolinjivadi et al. 2014, Nyongesa et al. 2016, Maithya et al. 2020), lack of supporting 
institutions such as bodies to offer certification and financial intermediaries (Katoomba group 2006), lack of awareness about the PES idea, limited capacity to design and implement the PES schemes and land tenure insecurity (Muramira 2005, Mwangi and Mutunga 2005, Katoomba group 2006, Ochieng et al. 2007, Nyongesa et al. 2016).

Local people perceive and value ecosystem services surrounding them, and therefore, it is important to assess their knowledge and values in connection to ecosystem services use and management (Meijaard et al. 2013, Brancalion et al. 2014). This perception is important to avail valuable information to develop and adapt policy and management guidelines (Asah et al. 2014, De Oliveira and Berkes 2014, Sandhu and Sandhu 2014). In the case of PES, this information enables a better understanding of PES participants on the driving force towards management decisions, which is crucial in improving management strategies (Balvanera et al. 2012). Fewer studies have addressed the local community's awareness on PES as a strategy to improve community livelihood and protection of wetlands (O'Farrell et al. 2007, de Chazal et al. 2008, Pieroni and Giusti 2009, Quétier et al. 2010, Lamarque et al. 2011, van Riper et al. 2012, Hutchinson et al. 2015). This informs the basis for this paper, to augment the growing demands for literature on the awareness to PES (Pieroni and Giusti 2009, Quétier et al. 2010, Lamarque et al. 2011, van Riper et al. 2012) and to build on the premise that studies on the local community's awareness on PES for improved community livelihood and protection of wetlands in Kenya are scanty in current literature.

The Kenyan wetlands have been valued as they are sources of many goods and services (Oduor et al. 2015, Nasongo et al. 2015, Ajwang' et al. 2016). Nyando wetland provides provisioning ecosystem goods such as fuel wood, food, fibers, fresh water, papyrus reeds, sand and clay, medicinal plants and grasses. Cultural services provided by wetlands include aesthetic values, recreational, spiritual and educational services, while climate regulation, water purification, soil erosion control, control of water hydrological flows and habitat provision are some of the regulating services provided by the wetlands (Maithya et al. 2020). Population increase along the Lake Victoria basin has exerted much pressure on the wetlands as people clear them for agricultural production, settlements and intensive fishing hence shrinking the lake's shoreline (Morrison et al. 2012, Osumba et al. 2010). The continued encroachments and clearing of vegetation cover have resulted to a decline in the usefulness of these Kenyan wetlands. Land tenure insecurity, lack of access to environmental information, lack of civic access, weak sectorial strategies to resource administration and inefficient governance are some of the threats facing the Kenyan wetlands (Maithya et al. 2020). Turner et al. (2003) observed that many ecosystems including wetlands are affected by climate change, and this increases the vulnerability of populations living in their surroundings. For instance, increased incidences of drought, results into crop failure, scarcity of animal feeds and loss of livelihoods which leads to further encroachments into the wetlands since they remain moist during the dry season. Due to the many benefits of the Kenyan wetlands to the local communities, their loss leads to deprivation of their livelihoods (Maithya et al. 2020) and thus PES may offer better impetus for enhancing their livelihoods and wetland conservation. Further from the forgoing discussions, this paper is aimed at understanding the local community's level of awareness of the ecosystem services provided by Nyando wetland as a strategy to improve conservation of the wetland by local communities and conservation authorities.

\section{Materials and Methods \\ Study area}

The study was conducted in Nyando wetland which is part of Nyando and Nyakach sub-counties of Kisumu County, Kenya (Figure 1). Nyando wetland lies in the Kano plains at the mouth of the Nyando River and along the shores of Lake Victoria between $0^{\circ} 11^{\prime}-0^{\circ}$ 
$19^{\prime} \mathrm{S} / 34^{\circ} 47^{\prime}-34^{\circ} 57^{\prime} \mathrm{E}$ (Raburu et al. 2012; Figure 1). It is a substantial floodplain forming major Nyakach and Kano swamps with an average elevation of $1134 \mathrm{~m}$ above the sea level. The main source of water to the wetland is from River Nyando, which originates from the Mau escarpment. Nyando wetland size varies from $3000 \mathrm{Ha}$ to $5000 \mathrm{Ha}$ in the dry and wet seasons, respectively (Kipkemboi 2006, Mwakubo and Obare 2009). Nyando wetland is of great ecological importance and supports the livelihoods and subsistence economy of the riparian communities. This is manifested through subsistence agriculture, freshwater fisheries, and tourism, transport as well as being sources of water for domestic and livestock use (Gichuki et al. 2001, Ogutu et al. 2003). A wide range of biodiversity is supported by this wetland ecosystem, i.e., the endangered Sitatunga, African civet and flora such as the papyrus (Obiero et al. 2012).
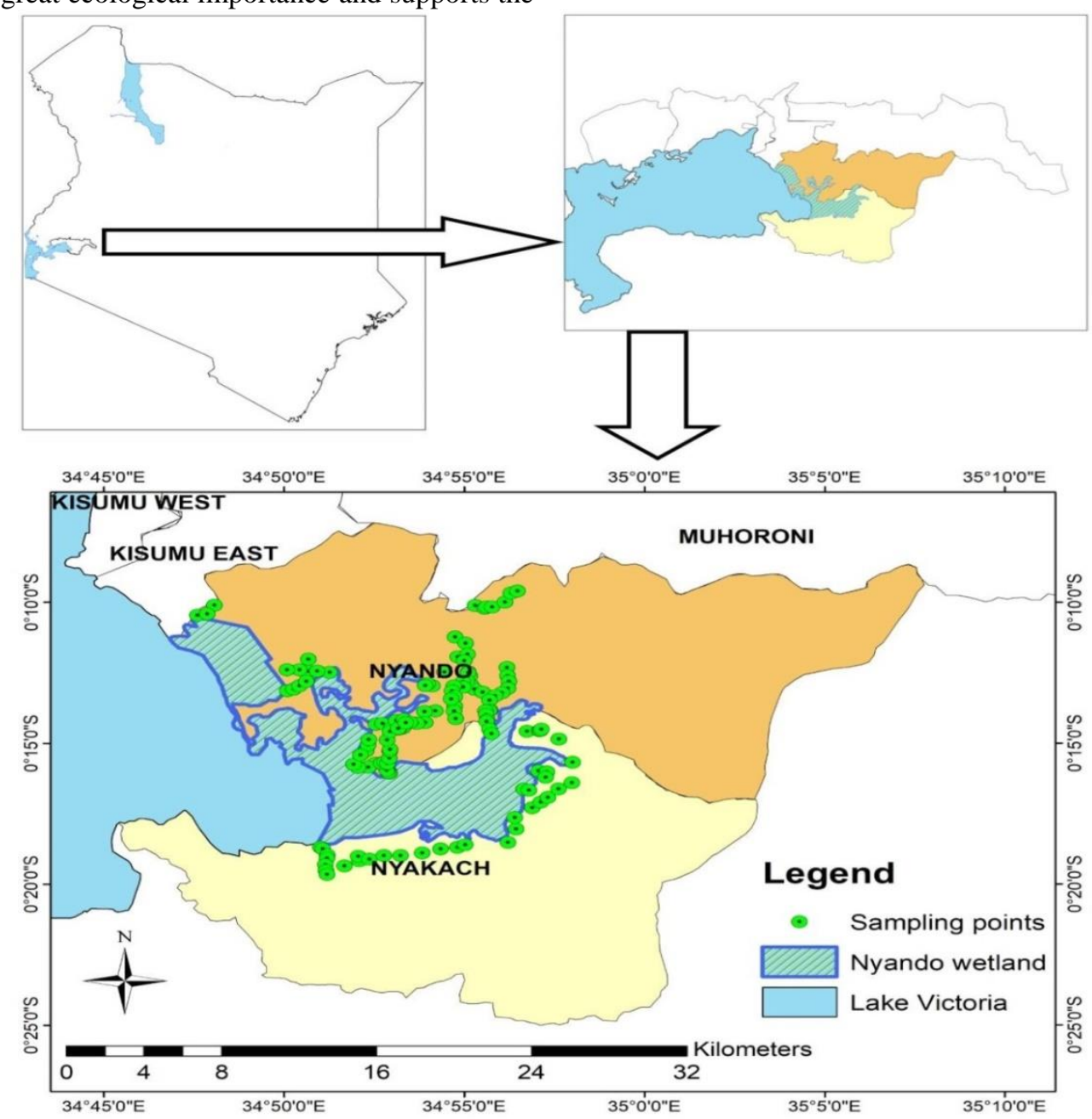

Figure 1: Location of Nyando wetland and sampling points. 


\section{Data collection procedures}

This paper is based on a case study survey design approach. Case studies enable one to have a holistic study of complex social and actions due to their ability to allow information gathering from multiple sources (Ming'ate 2014). A case study survey design approach relies on multiple data sources, a strategy which enhances data credibility (Yin 1994). The study employed quantitative and secondary sources of data collection (Crotty 1998). The total number of households which formed the population for this study was 16,226 respondents. The sample size was derived using the Yamane (1967) formula;

$$
\mathrm{n}=\frac{\mathrm{N}}{1+\mathrm{N}(\mathrm{e})^{2}}
$$

where $\mathrm{n}$ is the sample size, $\mathrm{N}$ is the population size, and ' $\mathrm{e}$ ' is the level of precision (at $5 \%$ ). Therefore, from a total of 16,226 households within the sampled sub-locations, the total sample size is calculated as follows:

$$
\mathrm{n}=\frac{16,226}{1+16,226(0.05)^{2}}=391 \text { households }
$$

A questionnaire was used to collect quantitative data from 394 households of Nyando and Nyakach sub-counties. The questionnaires were distributed proportionately per sub-location households in the two subcounties. The data collected included awareness on PES, local community's knowledge of ecosystem services from Nyando wetland and their beneficiaries, the need to conserve the wetland, organizations disseminating information on ecosystem services and their markets as well the local community's expectations from the PES schemes. The secondary data sources used included journals articles, books and reports from governmental and non-governmental agencies. All the quantitative data collected were edited, coded, tabulated and analyzed using SPSS version 20 (Braun and Clarke
2006). The analysis involved subjecting the data to descriptive statistics and Chi-square test at 5\% level of significance. A research permit was obtained from the National Council for Science, Technology and Innovations (NACOSTI) before undertaking the research. Additionally, consent from the participants was sought before conducting questionnaire administration. Nobody was victimized for not accepting to be interviewed.

\section{Results and Discussion \\ Local community's awareness of ecosystem services in Nyando wetland}

Majority of the respondents $(90.8 \%)$ had knowledge of the Nyando wetland ecosystem services with $96.9 \%$ attributing the wetland as valuable to them and the community at large. About $41.9 \%$ of respondents felt that they are informed on the ecosystem services from Nyando wetland (Table 1). These responses on the level of awareness on ecosystem services were significantly influenced by the level of education and respondent's locality $(\mathrm{p}<0.01$; Table 1). Chen et al. (2018) and Xun et al. (2017) noted that respondents having more years of formal education can perceive many ecosystem services. The level of education varied across the two sampled sub-counties, and this could have contributed to the above differences as knowledge on varieties of environmental resources requires some level of education. Overall, $64.8 \%$ of all the respondents had primary level education, $21.6 \%$ secondary education, while $3.3 \%$ and $10.3 \%$ had college and no education, respectively. Of those with college education, $69.2 \%$ were from Nyakach sub-county as compared to $30.8 \%$ from Nyando sub-county. Those with higher levels of education are able to understand and value nature better, which explains the observed differences. 
Maithya et al. - Local Communities' Awareness on Payments for Ecosystem Services ...

Table 1: Respondents level of awareness on ecosystem services from Nyando wetland

\begin{tabular}{lcccc}
\hline \multirow{2}{*}{ Response } & \multicolumn{2}{c}{ Frequency } & & \\
\cline { 2 - 5 } & $\mathrm{N}$ & $\%$ & Education level & Respondents locality \\
\hline Fully informed & 26 & 6.6 & & \\
Informed & 164 & 41.9 & & \\
Moderately informed & 111 & 28.4 & $26.677^{*}$ & $14.592^{*}$ \\
Partly informed & 76 & 19.4 & & \\
Not informed & 14 & 3.6 & & \\
\hline$* \chi 2$ significant at $\mathrm{p}<0.01$. & & &
\end{tabular}

The respondents were asked to rank the kinds of ecosystem services they were aware of from the wetland based on the four main classes (MEA 2005) of ecosystem service categories. The results indicate that about $37.7 \%$ of respondents were aware of provisioning ecosystem goods, e.g. fruits, vegetables, fish, drinking water, timber, wood fuel, plants that can be made into clothes and medicinal products. This is followed by regulating services at $32.1 \%$, e.g. pollination, water purification, erosion and flood control, carbon storage and climate regulation. Cultural services (aesthetic, spiritual, educational, and recreational) were noted by $18.6 \%$, while supporting services (nutrient cycling, soil formation and primary production) by $11.6 \%$ (Figure 2). The high ranking of provisioning services (goods) could possibly be because majority of the respondents interact with them more often as they derive direct benefits from them for their livelihoods. The results (Figure 2) also show that the respondents rarely identified supporting ecosystem services and this also concurs with other studies (Lamarque et al. 2011, Lugnot and Martin 2013). This could probably be due to the indirect impacts the supporting services have on the local people of Nyando wetland, and the fact that one requires some knowledge on ecological aspects to understand them. The age of the respondents significantly influenced their perceptions on supporting ecosystem services ( $<<0.05$; Table 2). This could be so as those who had attained the highest level of education (secondary and college) were between the ages 36-62 years and were able to identify many supporting ecosystem services (Table 2).

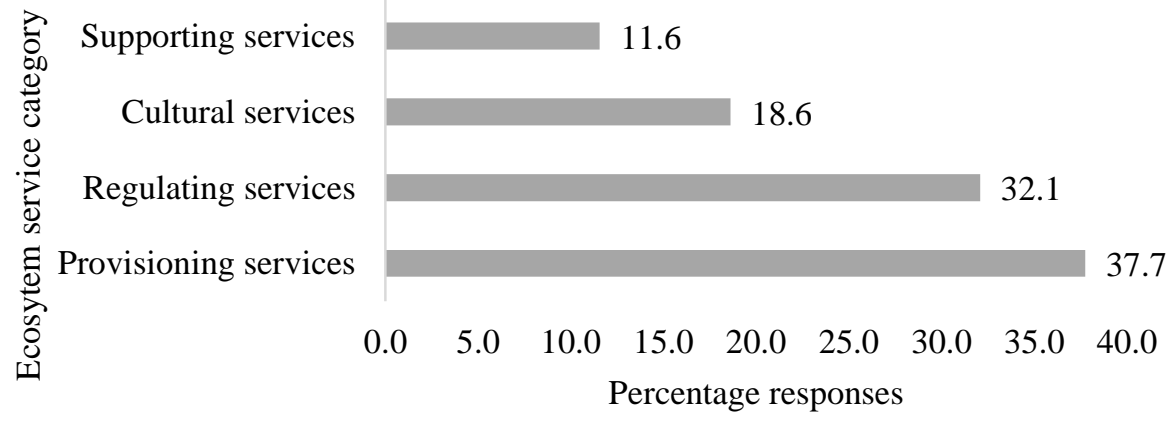

Figure 2: Knowledge of categories of ecosystem services by local community in Nyando wetland. 
Table 2: Perception on supporting ecosystem services as influenced by respondents age

\begin{tabular}{lcccccl}
\hline $\begin{array}{l}\text { Age } \\
\text { category } \\
\text { (Years) }\end{array}$ & $\begin{array}{c}\text { Primary } \\
\text { production }\end{array}$ & $\begin{array}{c}\text { Nutrient } \\
\text { cycling }\end{array}$ & $\begin{array}{c}\text { Soil } \\
\text { formation }\end{array}$ & Total & $\begin{array}{c}\text { Chi-square } \\
\left(\boldsymbol{\chi}^{2}\right)\end{array}$ & Remarks \\
\hline $18-26$ & 4 & 1 & 1 & 6 & & $* \chi^{2}$ \\
$27-35$ & 10 & 9 & 7 & 26 & $21.523^{*}$ & significant \\
$36-44$ & 24 & 8 & 18 & 50 & & at $\mathrm{p}<$ \\
$45-53$ & 15 & 16 & 13 & 44 & & 0.05. \\
$54-62$ & 20 & 4 & 20 & 44 & & \\
$>63$ & 8 & 8 & 20 & 36 & & \\
Total & $\mathbf{8 1}$ & $\mathbf{4 6}$ & $\mathbf{7 9}$ & $\mathbf{2 0 6}$ & & \\
\hline
\end{tabular}

On the provisioning ecosystem goods, food scored high $(37.6 \%)$, while fresh water, fuel and fibers and medical extracts scored $27.2 \%$, $23.9 \%$ and $11.2 \%$, respectively (Table 3 ). In the regulating category, it is apparent that more households were aware of climate regulation $(35.7 \%)$, erosion regulation $(20.9 \%)$, natural hazard regulation $(20.6 \%)$, water purification $(15.8 \%)$ and pollination (7.0\%). Climate regulation scores high probably because majority of the respondents stay close to the wetland and enjoys a cool micro-climate provided by the wetland (Table 3). In cultural ecosystem services, respondents were more aware of education $(35.3 \%)$, followed by aesthetic values (33.3\%) and spiritual and religious values $(11.2 \%)$ (Table 3$)$. Majority of respondents reported that cultural activities, especially spiritual attachments to the Nyando wetland have decreased in the area over the last decades due to inculcation of western values, religion and education, which have challenged communities' traditional beliefs and promoted diffusion of new modes of life (Arowolo 2010). On supporting services based on ranking of awareness by the respondents indicated that soil formation scored high (45.5\%), followed by nutrient cycling $(28.1 \%)$ and primary production at $26.1 \%$ (Table 3 ).

Table 3: Community familiarity with Nyando wetland ecosystem goods and services

\begin{tabular}{llll}
\hline Ecosystem goods and services & Frequency $(\mathrm{N})$ & Percentage \% \\
\hline Provisioning & Food & 381 & 37.6 \\
& Fresh water & 275 & 27.2 \\
& Fuel and fibers & 242 & 23.9 \\
& Medicinal extracts from plants & 113 & 11.2 \\
Regulating & Others & 1 & 0.1 \\
& Climate regulation & 307 & 35.7 \\
& Erosion regulation & 180 & 20.9 \\
& Natural hazard regulation & 177 & 20.6 \\
& Water purification & 136 & 15.8 \\
Cultural & Pollination & 60 & 7.0 \\
& Educational & 176 & 35.3 \\
& Aesthetic & 166 & 33.3 \\
Supporting & Recreation & 101 & 20.2 \\
& Spiritual and religious values & 56 & 11.2 \\
& Soil formation & 141 & 45.5 \\
& Nutrient cycling & 87 & 28.1 \\
& Primary production & 81 & 26.1 \\
\hline
\end{tabular}


The local communities at Nyando wetland were aware of the ecosystem services albeit at different levels and believe they are the main beneficiaries of the ecosystem services from Nyando wetland (53.9\%) as compared to other organizations (Figure 3). In line with conservation, a strong appreciation of something could translate to high level of endowment, and hence more efforts to safeguard it from misuse.

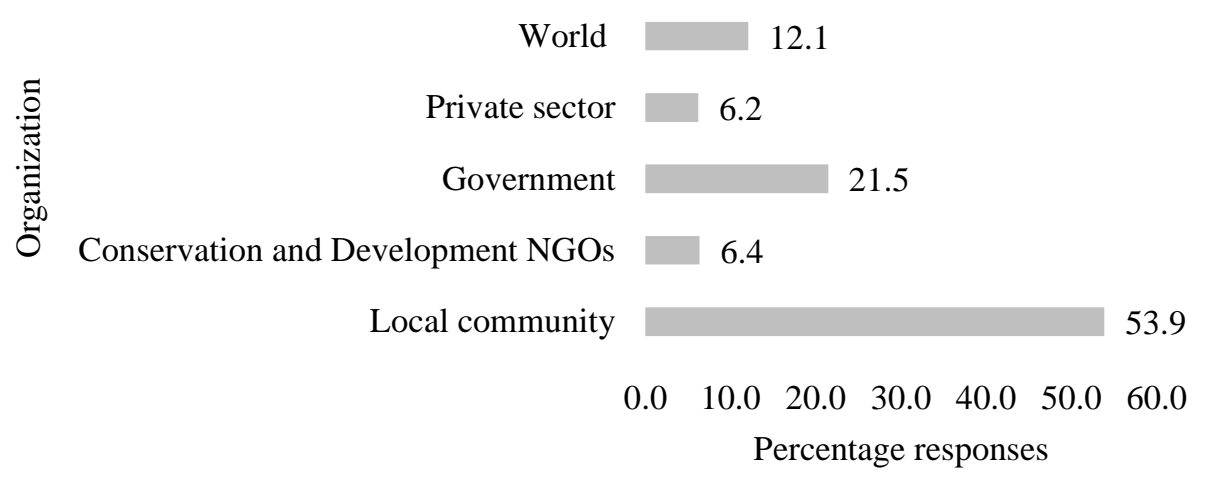

Figure 3: Beneficiaries of Nyando wetland ecosystem services as reported by respondents.

Awareness of Nyando wetland ecosystem services is further reinforced by a strong feeling from the respondents that they need to protect the wetland. Majority of them ranked wetland protection as important $(39.9 \%)$ and very important (55.6\%) compared to little or no importance at 0.8 and $0.3 \%$, respectively (Table 4). This awareness could probably be as a result of high values of attachments the respondents have to the wetland as their source of livelihood.

Table 4: Respondents responses on needs to protect the Nyando wetland

\begin{tabular}{lcc}
\hline Responses & Frequency & Percentage \\
\hline Very & 212 & 55.6 \\
important & & \\
Important & 152 & 39.9 \\
$\begin{array}{l}\text { Moderately } \\
\text { important }\end{array}$ & 13 & 3.4 \\
$\begin{array}{l}\text { Of little } \\
\text { importance }\end{array}$ & 1 & 0.3 \\
$\begin{array}{l}\text { Not } \\
\text { important }\end{array}$ & 3 & 0.8 \\
Total & $\mathbf{3 8 1}$ & $\mathbf{1 0 0 . 0}$ \\
\hline
\end{tabular}

Majority of the respondents (74.3\%) acknowledged that the continued existence of the Nyando wetland resources is not secure as a result of continued over-exploitation, climate change, and pollution. Despite the locals being involved in community based natural resource conservation initiatives, quite a high proportion of the respondents (69\%) are not familiar of the concept of PES as a result of lack of information. On the markets for ecosystem services, only $30.2 \%$ were aware of them, with the majority being aware of local markets for provisioning goods. One of the reasons raised for the low knowledge of markets for these ecosystem services is lack of information on the ecosystem services and how each can be sold. This is despite many organizations operating in the area involved in capacity building. Therefore, the concept of PES is not being addressed as part of the conservation strategies by these organizations.

Majority of the respondents (98.7\%) showed their willingness to know more on PES and their markets. They also showed their readiness $(88.5 \%)$ to change their land use practices to other sustainable uses with $69.3 \%$ saying that if compensated, they would release 
their land portions for wetland restoration. The respondents expect such PES schemes to bring additional income $(33.2 \%)$, better infrastructure (20.5\%) and technical assistance (16.1\%) (Figure 4). When asked to name some of the barriers that may hinder the adoption of PES schemes in the area, lack of capacity $(41.3 \%)$, lack of market information $(28.4 \%)$, and lack of community organization (22\%) were listed; with only $8 \%$ saying they were not interested. The willingness by the local community to accept PES is crucial so as to improve the quality of provisioning goods, improvement of supporting, cultural and regulating services (Nyongesa et al. 2016). This will enhance the sustainability of these wetland ecosystem services due to reduced over-exploitation as the locals are compensated to undertake conservation projects which results to diversified income hence improved livelihoods.

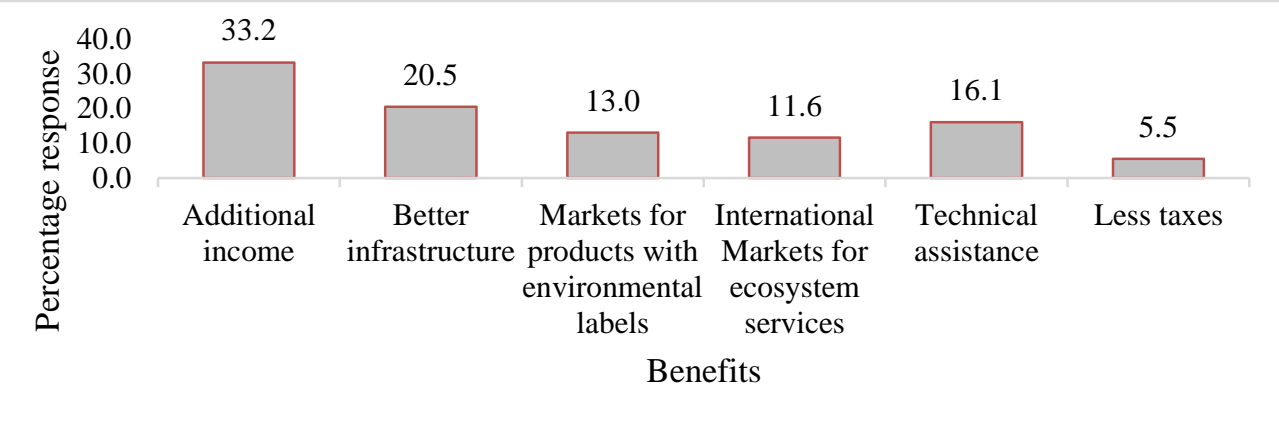

Figure 4: Respondents expectations from PES schemes.

\section{Conclusions and Policy Options}

Nyando wetland is endowed with several ecosystem goods and services including provisioning, regulating, cultural and supporting services. However, this paper has established that the local communities are more conversant with the provisioning ecosystem goods, hence its high perception as compared to the other three categories of ecosystem services from the wetland. The comparatively lower rank assigned to regulating, cultural, and supporting services calls for the government and non-state actors to raise awareness about the importance of all the wetland ecosystem services. This could contribute to better management, sustainable use and conservation of the wetland ecosystem goods and services and improved livelihoods of the local communities. The local communities at Nyando wetland have inadequate knowledge about the PES idea, thus the need to create awareness as well as continued engagement of the local communities through trainings and capacity building on the ecosystem services and conservation approaches.

\section{Declaration of Conflict of Interest}

The authors declare no conflict of interest

\section{References}

Ajwang' O, Kitaka RN and Oduor SO 2016 Assessment of provisioning and cultural ecosystem services in natural wetlands and rice fields in Kano Floodplain, Kenya. Ecosystem Services 21: 166-173.

Arowolo D 2010 The effects of western civilization and culture on Africa. Afro. Asian J. Soc. Sci. 1(1): 1-13.

Asah ST, Guerry AD, Blahna DJ and Lawler JJ 2014 Perception, acquisition and use of ecosystem services: Human behavior, and ecosystem management and policy implications. Ecosyst. Services 10: 180-186.

Atkinson G, Bateman I and Mourato S 2012 Recent advances in the valuation of ecosystem services and biodiversity. Oxford Rev. Eco. Policy 28(1): 22-47. 
Báliková K, Červená T, De Meo I, De Vreese R, Deniz T, El Mokaddem A and Paletto A 2020 How do stakeholders working on the forestwater nexus perceive payments for ecosystem services? Forests 11(1): 12.

Balvanera $\mathrm{P}$, Uriarte $\mathrm{M}$, Almeida-Lenero L, Altesor A, DeClerck F, Gardner T, Hall J,Lara, A, Laterra P, Peña-Claros $\mathrm{M}$ and Matos DMS 2012 Ecosystem services research in Latin America: The state of the art. Ecosyst. Services 2:56-70.

Berttram D 2011 Payments for ecosystem services-a feasible mechanism for natural resource management in East Africa? Taking stock and preparing to advance. MSc thesis, Utrecht University, the Netherlands.

Brancalion PHS, Cardozo IV, Camatta A, Aronson J and Rodrigues RR 2014 Cultural ecosystem services and popular perceptions of the benefits of an ecological restoration project in the Brazilian Atlantic. Restoration Ecol. 22: 65-71.

Braun V and Clarke V 2006 Using thematic analysis in psychology. Qualitative Res. Psychol. 3(2): 77-101.

Chen Y, Yu Z, Li X and Li P 2018 How agricultural multiple ecosystem services respond to socioeconomic factors in Mengyin County, China. Sci. Total Environ. 630: 1003-1015.

Crotty M 1998 The foundation of social research. SAGE Publications: London.

De Chazal J, Quétier F, Lavorel S and Van Doorn A 2008 Including multiple differing stakeholder values into vulnerability assessments of socio-ecological systems. Glob Environ Change 18: 508-520.

De Oliveira LEC and Berkes F 2014 What value S ao Pedro's procession? Ecosystem services from local people's perceptions. Ecol. Econ. 107: 114-121.

Dressler W 2011 From first to third nature: The rise of capitalist conservation on Palawan Island, the Philippines. J. Peasant Stud. 38(3): 533-557.

Ferraro PJ 2009 Regional review of payments for watershed services: Sub-Saharan Africa. $J$. Sustain. Forestry 28(3-5): 525-550.

Gichuki J, Guebas FD, Mugo J, Rabuor CO, Triest L and Dehairs F 2001 Species inventory and the local uses of the plants and fishes of the Lower Sondu Miriu wetland of Lake Victoria, Kenya. Hydrobiologia 458:99106.

Gómez-Baggethun E and Ruiz-Perez M 2011 Economic valuation and the commodification of ecosystem services. Progress Phys. Geo. 35: 613-628.

Gómez-Baggethun E, Martín-López B, Barton D, Braat L, Saarikoski H, Kelemen M, GarcíaLlorente E, van den Bergh J, Arias P, Berry PL, Potschin M, Keene H, Dunford R, SchröterSchlaack C and Harrison P 2014 State-of-the-art report on integrated valuation of ecosystem services. European Commission FP7 4: 1-33.

Greiber T 2009 Payments for Ecosystem Services. Legal and Institutional Frameworks. IUCN, Gland, Switzerland. xvi + 296 pp.

Hutchinson L, Montagna P, Yoskowitz D, Scholz D and Tunnell J 2015 Stakeholder perceptions of coastal habitat ecosystem services. Estuaries and Coasts 38(1): 67-80.

Katoomba Group 2006 Summary of country-level PES inventories carried out in East and South Africa. East and Southern Africa Katoomba Group, Kampala, Uganda.

Kipkemboi J 2006 Fingerponds: Seasonal integrated aquaculture in East African freshwater wetlands. Exploring their potential for wise use strategies. $\mathrm{PhD}$ dissertation, Institute if Water Education and IHE-Delft, Netherlands.

Kolinjivadi V, Adamowski J and Kosoy N 2014 Recasting payments for ecosystem services (PES) in water resource management: A novel institutional approach. Ecosystem Services 10:144-154.

Kronenberg J and Hubacek K 2013 Could payments for ecosystem services create an "ecosystem service curse"? Ecology and Society 18(1):10.

Lamarque P, Tappeiner U, Turner C, Steinbacher M, Bardgett RD, Szukics U, Schermer M and Lavorel S 2011 Stakeholder perceptions of grassland ecosystem services in relation to knowledge on soil fertility and biodiversity. Reg. Environ. Change 11: 791-804.

Lecocq F and Capoor K 2005 State and trends of the carbon market. Geneva, Switzerland: International Emissions Trading Association. 
Li T 2007 The will to improve: Governmentality, development, and the practice of politics. Durham: Duke University Press.

Lugnot M and Martin G 2013 Biodiversity provides ecosystem services: Scientific results versus stakeholders' knowledge. Reg. Environ. Change 13: 1145-1155.

MEA (Millennium Ecosystem Assessment) 2005 Millennium ecosystem assessment. Ecosystems and Human Well-being. Island Press, Washington DC.

Maithya JK, Ming'ate FLM and Letema SC 2020 A review on ecosystem services and their threats in the conservation of Nyando Wetland, Kisumu County, Kenya. Tanz. J. Sci. 46(3): 711-722.

Meijaard E, Abram NK, Wells JA, Pellier AS, Ancrenaz M, Gaveau DLA, Runting RK and Mengersen K 2013 People's perceptions about the importance of forests on Borneo. PLoS One 8: e73008.

Ming'ate FL 2014 Combining ethnography and case study research designs in studying forestry co-management approaches. $J$. Human Soc. Sci. Res. 3(2): 67-79.

Morrison EHJ, Upton C, Odhiambo-K'oyooh K and Harper DM 2012 Managing the natural capital of papyrus within riparian zones of Lake Victoria, Kenya. Hydrobiologia 692(1): 5-17.

Muramira TE 2005 Overview of payment for ecosystem services in Uganda. Presentation at the workshop Building Foundations for ProPoor Ecosystem Service Payments in Africa, Queen Elizabeth National Park, Uganda.

Mwakubo SM and Obare GA 2009 Vulnerability, livelihood assets and institutional dynamics in the management of wetlands in Lake Victoria watershed basin. Wetlands Ecol. Manag. 17(6): 613-626.

Mwangi S and Mutunga C 2005 Overview of PES in Kenya. Presentation at the workshop on Building Foundations for Pro-Poor Ecosystem Service Payments in Africa, Queen Elizabeth National Park, Uganda.

Nasongo S, Zaal F, Dietz AJ and Okeyo-Owuor JB 2015 Institutional pluralism, access and use of wetland resources in the Nyando Papyrus Wetland, Kenya. J. Ecol. Nat. Environ. 7 (3): 56-71.
Noorwijk M and Leimona B 2010 CES/COS/CIS Paradigms for Compensation and Rewards to Enhance Environmental Services. Working Paper, 100. World Agroforestry Centre (ICRAF). Bogor, Indonesia.

Nyongesa JM, Bett HK, Lagat JK and Ayuya OI 2016 Estimating farmers' stated willingness to accept pay for ecosystem services: Case of Lake Naivasha watershed Payment for Ecosystem Services scheme-Kenya. Ecol. Processes 5(1): 1-15.

Obiero KO, Philip O, Okeyo-Owuor JB and Raburu E 2012 Community perceptions on the impact of the recession of Lake Victoria Waters on Nyando Wetland. Sci. Res. Essays 7(16): 1647-1661.

Ochieng B, Otiende B and Rumley R 2007 African regional workshop on compensation for ecosystem services (CES), May 22-24, 2006, Nairobi, Kenya (ICRAF Working Paper No. 35). Nairobi, Kenya: World Agroforestry Centre.

Oduor FO, Raburu PO and Mwakubo S 2015 To conserve or convert wetlands: Evidence from Nyando Wetlands, Kenya. J. Develop. Agric. Econ. 7 (2): 48-54.

O'Farrell PJ, Donaldson JS and Hoffman MT 2007 The influence of ecosystem goods and services on livestock management practices on the Bokkeveld plateau, South Africa. Agric. Ecosyst. Environ. 122: 312-324.

Ogutu ZA, Okedi J and Okeyo-Owuor JB (Eds) 2003 Wetland research in the Lake Victoria Basin, Analysis and Synthesis. Lake Victoria Research Initiative (VicRes). IUCEA.

Osumba JJL, Okeyo-Owuor JB and Raburu PO 2010 Effect of harvesting on temporal papyrus (Cyperus papyrus) biomass regeneration potential among swamps in Winam Gulf wetlands of Lake Victoria Basin, Kenya. Wetlands Ecol. Manag. 18: 333-341.

Pagiola S, Arcenas A and Platais G 2005 Can payments for environmental services help reduce poverty? An exploration of the issues and the evidence to date from Latin America. World Develop. 33(2): 237-253.

Pieroni A and Giusti M 2009 Alpine ethnobotany in Italy: traditional knowledge of gastronomic and medicinal plants among the Occitans of the upper Varaita valley, Piedmont. $J$. Ethnobiol Ethnomed. 5: 32. 
Quétier F, Rivoal F, Marty P, de Chazal J, Thuiller W and Lavorel S 2010 Social representations of an alpine grassland landscape and socio-political discourses on rural development. Reg. Environ. Change 10:119-130.

Raburu PO, Okeyo-Owuor JB and Kwena F 2012 Community Based Approach to the Management of Nyando Wetland, Lake Victoria Basin, Kenya. http://www.ke.undp.org/content/dam/kenya/d ocs/energy_and_environment/Nyando $\% 20 \mathrm{Bo}$ ok\%20-\%20FINAL\%20MOST-internet.pdf

Sandhu H and Sandhu S 2014 Linking ecosystem services with the constituents of human wellbeing for poverty alleviation in eastern Himalayas. Ecol. Econ. 107: 65-75.

Scurrah-Ehrhart C 2006 Tanzania inventory of payments for ecosystem services. Washington, DC: Forest Trends.

Sommerville MM, Jones JPG and Milner-Gulland EJ 2009 A Revised conceptual framework for payments for environmental services. Ecol. Soc. 14(2): 34.

Swallow BM, Kallesoe U, Iftikhar M, van Noordwijk C, Bracer S, Scherr KV, Raju S, Poats A, Duraiappah B, Ochieng H, Mallee and Rumley R 2007 Compensation and Rewards for Environmental Services in the Developing World: Framing Pan-Tropical Analysis and Comparison. World Agroforesty Centre (ICRAF) Working Paper, 32. Nairobi, Kenya.

To PX, Dressler WH, Mahanty S, Pham TT and Zingerli C 2012 The prospects for payment for ecosystem services (PES) in Vietnam: a look at three payment schemes. Human Ecol. 40(2): 237-249.

Turner BL, Kasperson RE, Matson PA, McCarthy JJ, Corell RW, Christensen L, Eckley N Kasperson, JX, Luers A, Martello ML and Polsky C 2003 A framework for vulnerability analysis in sustainability science. Proc. Natl. Acad. Sci. USA 100 (14): 8074-8079. van Riper CJ, Kyle GT, Sutton SG, Barnes M and Sherrouse BC 2012 Mapping outdoor recreationists' perceived social values for ecosystem services at Hinchinbrook Island National Park, Australia. Appl. Geo. 35: 164173.

Waage S, Scherr S, Jenkins M and Inbar M 2006 A scoping assessment of current work on payments for ecosystem services in Asia, Latin America, and East \& Southern Africa. Adapted from the full report submitted to the UNDP-GEF project: Institutionalizing Payments for Ecosystem Services, Supplement III. Building National Capacity for PES.

Wanjohi LW, Kipkoech A, Mwaura F, Kagure E, Makala M and Otieno J 2011 Valuation of Yala Swamp for biodiversity conservation and poverty reduction. In: Towards Implementation of Payment for Environmental Services (PES): a collection of findings linked to the ASARECA funded research activities, 228-248 pp. VDM Verlag Dr. Müller, Saarbrücken, 404 p.

Wunder S 2005 Payments for environmental services: Some nuts and bolts. CIFOR Occasional Paper, vol. 42. CIFOR, Bogor.

Wunder S and Boerner J 2010 Changing land-use in forestry and agriculture through payments for environmental services. In: Yu HungHong et al. (Eds.). The Environment, Climate Change, and Land Policies. Lincoln Institute: Cambridge (MA).

Xun F, Hu Y, Lv L and Tong J 2017 Farmers' awareness of ecosystem services and the associated policy implications. Sustainability 9: 1612.

Yamane T 1967 Statistics, An Introductory Analysis ( $2^{\text {nd }}$ ed.) New York: Harper and Row.

Yin RK 1994 Case study research: Design and methods $\left(2^{\text {nd }}\right.$ ed.) Thousand Oaks CA: Sage. 